\title{
Dynamics of suffix - gate in culture and language
}

\author{
Larisa Kulgavova ${ }^{1 *}$ \\ ${ }^{1}$ Irkutsk State University, 1 Karl Marx St., Irkutsk, Russia
}

\begin{abstract}
The article considers the origin of the word-building formant -gate and the change of its morphological status from a splinter into an affix (a suffix). The article describes the dynamics of its conceptual senses and the actual language content in the $70 \mathrm{~s}, 80 \mathrm{~s}, 90 \mathrm{~s}$ of the last century and at the beginning of the XXI century and shows its cultural conditionality upon the events of the corresponding periods. Particular attention is paid to the differences in the conceptual component of this sign in the American and British linguistic cultures. The predominance of the ludic function of the suffix over its informative function in recent years in the mass media is emphasized.
\end{abstract}

\section{Introduction}

The suffix -gate owes its origin to the word Watergate. The word Watergate is part of the Watergate scandal the name of the high-profile political scandal of 1972-1974 in the United States, which ended with the resignation of President Richard Nixon.

On June 17, 1972, that is, four months before the 1972 presidential election, in which Republican candidate Richard Nixon was re-elected for a second term, burglars entered the headquarters of the Democratic National Committee in the Watergate Hotel, Washington DC, in order to install listening equipment and in search of materials that could be used by the Committee for the Re-election of the President against the Democratic presidential candidate George McGovern. The burglars were detained on the spot, and this affected Nixon's career after his victory in the 1972 election. The investigation into the case lasted for more than two years and led to his resignation in 1974.

\section{Results and discussion}

The word Watergate quickly acquired the generalized meaning of a political scandal and began to take part in the formation of telescoped words (blends), in which the first stem:

1) indicates the place of the scandal;

2) denotes the person or organization that is the culprit/participant of the scandal;

3 ) is the name of the subject (object) or activity related to the scandal.

The popularity of the model led to a change in the morphological status of -gate, which turned from a fragment element (a splinter from Watergate) as a result of reanalysis into a suffix used to form words with the meaning of a scandal or a secret that needs to be disclosed. J. Ayto gives the following definition to this suffix: -gate suffix (1973) an ending denoting an actual or alleged scandal (and usually an attempted cover-up), in some way comparable with the Watergate scandal of 1972 onwards [1]. Some sources emphasize the negative evaluative connotation of this suffix: -gate suf., added to any word, gives it a sharply negative connotation with a hint of a possible scandal, based on the model of Watergate [2].

For five decades of its existence, -gate has demonstrated the flexibility and variability of its linguistic (semantic) and conceptual content, which is due to various (political, economic, etc.) events in the life of society and its individual representatives. As N.F. Alefirenko points out, cognitive processes are in a certain correlation with the linguistic and cultural environment [3]. Any attempt to accurately and comprehensively describe all the lexical units formed by this suffix is obviously doomed to failure, since most of them are one-day coinages. According to the American Dialect Society, only during the period of the late 70 s early 80 s of the last century, about fifty words with the suffix -gate appeared in the English language [4]. Therefore, with the help of reference books, we will try to identify the key, most striking examples of each decade.

The popularity of the word Watergate in the 70s of the last century brought to life a large number of words related to the scandalous events of those years. The following lexical units are most often mentioned in the literature: Winegate (1973, the substitution of expensive French wines like Bordeaux with cheaper and lowerquality ones in France), Motorgate (1975, the scandal related to the warranty obligations of General Motors in Cleveland), Cattlegate (1976, infected cattle feed in Michigan), Koreagate (1976, the scandal about the corrupt influence of South Korea on the US Congress).

In the 80s, most words are associated with President Ronald Reagan and the activities of his administration. According to J. Ayto, the most famous example from the 80 s is Irangate (1986), related to the prohibited arms supplies to Iran and Nicaragua: "Probably the most

Corresponding author: laurkul@yandex.ru 
notorious example was Irangate (1986), a scandal involving allegations that profits from US arms sales to Iran had been diverted to aid anti-government guerrillas in Nicaragua" [1]. The scandal was so loud that it required the creation of a number of synonyms for its designation. Here is what S. Steinmetz writes about its survival into the 1980s: "The recent White House scandal [the Iran-Contra affair] has been a windfall for wordsmiths. ... First the five -gates came: Reagan's Watergate, Reagangate, Irangate, Contragate, and Armsgate" [5]. Among other words, one can mention Iraqgate (1989, the scandal that revealed that the Atlanta representative office of the largest Italian bank Banca Nazionale del Lavoro (BNL), relying on credit guarantees from the US government, sent more than $\$ 5$ billion to Iraq in the period from 1985 to 1989 , used for the purchase of weapons and weapons technologies.

In the 90s, the use of the suffix -gate was primarily associated with the scandals in Bill Clinton administration: Travelgate (1993, the scandal in which Hillary Clinton was accused of illegally firing employees of the White House Travel Office at her request, and their jobs were taken by Arkansas acquaintances of the presidential couple), Whitewatergate (the scandal with land plots in Arkansas, in which the Clinton spouses were allegedly involved). In the 90s, the suffix actually experienced a rebirth, acquiring additional sexual senses, as a result of the sensational scandal with Monica Lewinsky, in the words Monicagate, Lewinskygate, Zippergate, Sexgate, Tailgate, fornigate. These senses were further developed in connection with other events at the beginning of the XXI century in the words Nipplegate and Rooneygate.

We should also mention the words Squidgygate and Dianagate, denoting the scandal that began with the publication of a transcript of a telephone conversation between Princess Diana and her friend James Gilbey on August 23, 1992, and accelerated her divorce from Prince Charles. In a conversation held on December 31, 1989, the princess compared herself to the heroine of the TV series and complained about the attitude of the members of the royal family to her. Another high-profile scandal was called Camillagate. In 1992, there was a scandal that shocked the entire royal family: a 1989 recording of a telephone conversation between Prince Charles and his mistress Camilla Parker-Bowles appeared in the press. Then the prince received the nickname Mr. Tampax.

At the beginning of the XXI century, the gate-words are distinguished by a wider thematic diversity, since the suffix absorbed various senses of the first three decades of its functioning. Among the most famous words are Shawinigate (2001, the scandal involving the Canadian Prime Minister), skategate (2002, the scandal over biased judging in pair skating at the US Olympic Games), Katrinagate (2005, the US authorities' unpreparedness for Hurricane Katrina). As for the last word, members of the American Dialect Society even considered it as a candidate for the word-symbol of 2005.

The continuators of the list of words like Monicagate, Camillagate at the beginning of the XXI century include the words Nipplegate (also Boobgate) and Rooneygate, often mentioned in the reference literature. The word Rooneygate (2004) comes from the name of the British football player Wayne Rooney, who paid for the services of a prostitute with whom he had an affair. The appearance of the word Nipplegate is described by $\mathrm{K}$. Burridge in her book "Weeds in the Garden of Words": "I was delighted when I heard on ABC radio a number of references to nipplegate. I was beginning to worry that, despite zippergate, peckergate and fornigate (after the Clinton-Starr conflict), -gate words might be on the way out. Nipplegate, of course, referred to Janet Jackson's little stunt in early February 2004. Mid-show, at half-time during the Super Bowl match, Justin Timberlake ripped open Jackson's rather peculiarlooking bustier to reveal a right breast equipped with a silver nipple ornament. 'A wardrobe malfunction' was the explanation. A likely story, given the chic silver sunburst she just happened to be wearing at the time. The press smelled a rat - hence, nipplegate" [6].

As K. Burridge points out, the use of gate-words is associated with denoting fraud, deception, intrigue, manipulation: "Words ending in -gate usually tell a story of jiggery-pokery and hanky-panky" [6]. Of particular interest here is the use of such polysemous colloquial words as jiggery-pokery and hanky-panky, which in addition to the above-mentioned meanings have such senses as "absurd, nonsense, baloney" (jiggery-pokery) and "sexual game, flirting" (hanky-panky).

All this indicates that the functioning of the suffix -gate in the English language in recent years has been more ludic (in a broad sense) than informative. However, D.K. Barnhart and A. Metcalf suggest that its use was jocular already in the first years of its life, and cite as an example the word Volgagate to denote a fictional scandal in Russia: "At first it may have been just a joke; a 1973 issue of the humor magazine "National Lampoon" wrote of a fictional Volgagate in Russia" [7]. The -gate suffix is most often found in the mass media, especially in headlines, where diverse ludic intentions have various realizations. Journalists create occasional words denoting real or fictional scandals or pick up words that have already been coined by someone, and include them in their articles in order to draw attention to the published material and, according to S. Steinmetz, give piquancy to the described ("all nonce words used chiefly by newspapers and magazines to spice up their coverage of current news") [5].

Thus, both the word Watergate and the suffix -gate have undergone generalization as a result of their semantic development. The broad, generalized meaning of a public scandal (political or any other), coupled with various ludic effects, gives their use a touch of simulation. H. Oliver, for example, gives them a very original characteristic - "a handy catch-all term for whatever outrage comes along next" [8].

Despite the above, the development of generalized meanings by the word Watergate and the suffix -gate does not mean that geographical, political, historical and other senses have been lost in their concepts. In the minds of Americans, at least middle-aged and older people, any mention of -gate is associated with the name 
Watergate and with the events of the Watergate scandal, which is part of American history closely related to the president/presidency. An analysis of the texts of newspaper and magazine articles published abroad and in Russia shows that journalists associate the suffix -gate and the words formed by it with the era of a particular president. So, in the Ukrainian newspaper "Day" (2005) we find the following statement: "And if President Robert [sic!] Nixon had Watergate, Bill Clinton Monicagate, now George Bush has every chance to get his Katrinagate".

As for the British, the irrelevance of the events of the Watergate case for their own history and geographical remoteness contributed to the formation of a slightly different conceptual content in the suffix - more generalized and diverted from the original political events. In other words, small-scale word-formation models have national and cultural specifics from a cognitive and semantic point of view in various variants of the English language.

To confirm this position in this publication, we rely on the data of explanatory dictionaries and various reference books of the English language, as well as on the materials of encyclopedias and scientific publications of American and British scholars. Thus, in the definitions of American dictionaries, the connection of the meaning of the suffix with the historical events of the early 70s of the last century is traced or its ethnospecific component is found. Compare:

-gate - (suffix mainly journalism) sometimes used with nouns to make a name for a political scandal, especially one that affects the president or government of the U.S. From Watergate, a U.S. political scandal in 1972 that caused President Nixon to leave his job (Macmillan Dictionary);

-gate - a combining form extracted from Watergate, occurring as the final element in journalistic coinages, usually nonce words that name scandals resulting from concealed crime or other alleged improprieties in government or business: Koreagate (Random House Webster's Unabridged Dictionary).

In general English dictionaries and dictionaries focused on British English (unless they are dictionaries with elements of an encyclopedic character), this suffix is fixed with a more generalized meaning of scandal. Compare:

-gate (suffix) combined with keywords to form the names of scandals (Wiktionary);

-gate (combining form) indicating a person or thing that has been the cause of, or is associated with a public scandal: Irangate, Camillagate (Collins English Dictionary).

An analysis of the available scientific and reference literature shows that the American authors cite mainly words related to the realities of American life (in particular, the president and his entourage, leading politicians), while the British sources primarily pay attention to the vocabulary that records events related to the royal family or the activities of the British government.

Thus, American researchers D.K. Barnhart and A. Metcalf in their book "America in So Many Words:
Words That Have Shaped America" cite the words Volgagate, Winegate, Cattlegate, Motorgate, Travelgate, Whitewatergate [7]. Of these, the first two relate to the scandals in Russia and France, respectively (the first is fictional, the second is real), the remaining four relate to the events in the United States, and the last two are related to the president (Bill Clinton). A. Metcalf in his other book "Predicting New Words: The Secrets of Their Success", in addition to the above, writes about the words Irangate, Contragate, skategate, Shawinigate [9]. Of these, only the fourth refers to Canada, the rest - to the United States, the first and second of which denote the scandals during the presidency of Ronald Reagan. R. Keyes counts Irangate, Whitewatergate, Monicagate and Nipplegate as the linguistic legacy of Watergate [10]. All these words refer to certain events in American history, and the first three are directly related to the president. In the list of J. McQuain - Winegate, Iraqgate, Koreagate, Travelgate, Filegate, Whitewatergate, Zippergate, Sexgate, Monicagate - only the first word refers to the events in France, and all the others - in the United States (most of the events involved the president) [11]. R. Ostler in "Dewdroppers, Waldos, and Slackers: A Decade-by-Decade Guide to the Vanishing Vocabulary of the Twentieth Century" mentions mainly the words that owe their existence to various events in the life of Americans: Watergate, skategate, Altergate, Billygate, Debategate, Floodgate, Goldingate, Tailgate, Waste-watergate [4]. A similar situation is found in the books of S. Steinmetz (see [5, 12]): Watergate, Koreagate, Nannygate, Oilgate, Reagan's Watergate, Reagangate, Irangate, Contragate, Armsgate, Blagojevichgate, Spitzergate, Palingate, wardrobegate, troopergate, Cattlegate, Dallasgate, Hollywoodgate, Quakergate, Sewergate. Of these, only Oilgate is associated with the events in South Africa.

It is natural for the British authors to pay attention to the events in their country. So, among the examples given by S. Dent in [13], the first, fourth and fifth words are of American origin, while the rest are of British origin: Watergate, Cheriegate, Camillagate, Zippergate, Monicagate, Rooneygate, Nannygate. In general, there is a greater diversity in the works of British authors in terms of geography. For example, J. Ayto in his dictionaries [ 1 et al] emphasizes the prevalence of the suffix in the English-speaking countries and gives such examples: Watergate, Contragate, Irangate, Dallasgate, Gospelgate, Pearlygate (USA), Westlandgate (UK), Winegate (France), Muldergate (South Africa), Milliongate (Sierra Leone).

Thus, -gate is closely connected with the history of the United States and is associated by Americans with specific historical events and people, mainly with the president and his entourage, environment, activities. For the British, it is an immigrant suffix with a more generalized meaning and conceptual content. However, it should be noted that later the time factor would play a certain role for Americans: the events of the distant 70s will gradually be erased from the memory of an ordinary, average American, and the corresponding senses will disappear from the conceptual content of the lexical units with the suffix -gate. In the worst case for 
this suffix, it will ultimately go to the far periphery of the word-building processes. It is noteworthy that for some reason, S. Steinmetz and B.A. Kipfer already wrote about this in the past tense: "Combining forms that are least likely to endure are those triggered by a particular event, usually in politics. A prime example of this is the combining form -gate, derived from Watergate and widely applied in the media to any scandal resembling or suggesting the Watergate scandal... <...> As memories of Watergate faded, the combining form that it engendered faded as well" [12].

\section{Conclusion}

In conclusion, the following should be noted. The epithet "alive", often used in publications of recent years to describe the real functioning of lexical units, can be applied to the word-building formant -gate. Over five decades, -gate has undergone a comprehensive change. Firstly, there was a change in its morphological status from a splinter to a suffix as a result of reanalysis and as a consequence of the popularity of the model. The dynamics of its conceptual senses and the actual language content is culturally determined by the events of the corresponding periods. The conceptual diversity is explained, on the one hand, by its origin - the development from the full-meaning word Watergate, and on the other - by the connection with the names of other events with their conceptual "aura". The differences in the cognitive and linguistic planes of the suffix -gate in the American and British variants confirm the thesis that the content component of the small-scale word-building models has national and cultural specifics in the regional varieties of the English language. The study of such models is the key to identifying ways of encoding national-cultural information in lexical units. This information in suffixes of the -gate type is presented in two ways - semantically and conceptually. In recent years, there has been a tendency to create new coinages in which the informative function of this "journalistic" suffix is weakened or replaced by the attractive and ludic functions.

All of the above suggests that the suffix -gate is a bright example of the manifestation of such a property of the language sign as the ability to fluctuate. The uniqueness of this suffix lies in the fact that the fluctuation is created and manifests itself before our eyes.

\section{References}

1. J. Ayto, Movers and Shakers: A Chronology of Words That Shaped Our Age (Oxford University Press, Oxford, 2006)

2. Z.S. Trofimova, Slovar' novyh slov i znachenij $v$ anglijskom yazyke (Pavlin, Moskva, 1993)

3. N.F. Alefirenko, "ZHivoe slovo": Problemy funkcional'noj leksikologii: monografiya (Flinta, Nauka, Moskva, 2009)
4. R. Ostler, Dewdroppers, Waldos, and Slackers: A Decade-by-Decade Guide to the Vanishing Vocabulary of the Twentieth Century (Oxford University Press, Oxford, 2005)

5. S. Steinmetz, There's a Word for It: The Explosion of the American Language Since 1900 (Harmony Books, New York, 2010)

6. K. Burridge, Weeds in the Garden of Words: Further observations on the tangled history of the English language (Cambridge University Press, Cambridge, 2005)

7. D.K. Barnhart, A. Metcalf, America in So Many Words: Words That Have Shaped America (Houghton Mifflin Company, Boston, New York, 1997)

8. H. Oliver, March Hares and Monkeys' Uncles (Metro, London, 2005)

9. A. Metcalf, Predicting New Words: The Secrets of Their Success (Houghton Mifflin Company, Boston, New York, 2002)

10. R. Keyes, I Love It When You Talk Retro: Hoochie Coochie, Double Whammy, Drop a Dime, and the Forgotten Origins of American Speech (St. Martin's Griffin, New York, 2010)

11. J. McQuain, Home-Grown English: How Americans Invented Themselves and Their Language (Random House Reference, New York, 2002)

12. S. Steinmetz, B.A. Kipfer, The Life of Language: The Fascinating Ways Words are Born, Live and Die (Random House Reference, New York, Toronto, London, Sydney, Auckland, 2006)

13. S. Dent, Fanboys and Overdogs: The Language Report (Oxford University Press, Oxford, 2005) 